\title{
Comunicación

\section{Género, discurso crítico y violencia simbólica: un trinomio epistemológico en la prensa chilena entre 2006-2011}

Gender, critical discourse and symbolic violence:

A three-pronged epistemology of the Chilean press from 2006-2011

\section{PAULINA SALINAS MERUANE2 Y \\ CLAUDIA LAGOS LIRA 3}

Este artículo analiza las construcciones de género en la prensa nacional, durante el gobierno de la primera mujer presidenta en Chile (2006-2011). La llegada de Bachelet al gobierno no produjo una transformación efectiva en la manera de significar lo femenino: más bien existe continuidad y escasos cambios. Se advierte un uso naturalizado del lenguaje indirecto, develándose sexismo, control social y xenofobia.
This study presents the discourses of gender in the national press during the 2006-2011 government of the first woman president in Chile, Michelle Bachelet. The underlying hypothesis of this research is the triangulation between gender, discourse, and symbolic violence in the press. The findings reveal sexism, social control, and xenophobia.

KEY WORDS: Epistemology, gender, discourse, press, discrimination.

PALABRAS CLAVE: Epistemología, gé-
nero, discurso, prensa, discriminación.

1 Este artículo es parte del Proyecto Fondecyt Na1110009 "Modelos profesionales de periodismo en Chile. Roles institucionales, orientaciones epistemológicas y factores condicionantes de la prensa nacional durante el periodo 1990-2011".

2 Universidad Católica del Norte, Chile.

Correo electrónico: psalinas@ucn.cl

Av. Angamos 0610, Antofagasta, Chile.

3 Universidad de Chile, Chile.

Correo electrónico: cllagos@uchile.cl

Av. Ignacio Carrera Pinto 1045, Nuñoa; Santiago, Chile. 


\section{INTRODUCCIÓN}

El presente artículo examina las construcciones de género en la prensa chilena de cobertura nacional durante el gobierno de la primera presidenta mujer en Chile, Michelle Bachelet Jeria (2006-2011).4 Las desigualdades de género en el ámbito simbólico han sido analizadas en los medios de comunicación, la publicidad, los textos escolares, entre otros. El interés por comprender este periodo en su sentido discursivo se centra en develar las construcciones del género que se plasman en la prensa nacional, en un gobierno donde la mujer alcanza la primera magistratura y, junto con ello, se impulsa una medida inédita como la constitución de un gabinete paritario (Fries, 2010). Nos interesa responder cómo se construyen los discursos sobre las identidades de género en la prensa bajo la primera administración de una mujer en el país y si la llegada de Bachelet a la presidencia significó un cambio efectivo o bien, se trató de algo superficial.

La hipótesis es que estaríamos frente a un trinomio crítico entre género, discurso y violencia simbólica que contrapone -en oposición- lo femenino y lo masculino en la prensa escrita: ellos fuertes/ellas débiles; ellos líderes/ellas sumisas; ellos protagonistas/ellas subalternas. Hay una naturalización del lenguaje que favorece el uso imperceptible de figuras literarias que frivolizan el sentido del texto, lo ocultan, manipulan y encubren la discriminación de género.

La preocupación no es nueva, hay numerosa literatura que da cuenta de los desequilibrios de género en el ámbito de lo simbólico, especialmente en los medios y la publicidad, así como iniciativas tendientes a romper con ellos, como los manuales de comunicación y periodismo con perspectiva de género (DOMOS, 2011).

La llegada de Michelle Bachelet como la primera mujer a la presidencia del país es un eslabón fundamental en la sensibilización e insta-

4 Al cierre de la edición de este artículo, Michelle Bachelet había ganado las elecciones primarias y era la candidata a la presidencia de la República de la coalición Nueva Mayoría, heredera de la Concertación de Partidos por la Democracia, para las elecciones presidenciales de noviembre de 2014. 
lación de las desigualdades de género como un problema que merece la atención pública en Chile.

Desde la recuperación de la democracia en 1990 a la fecha, se han impulsado políticas y reformas tendientes a abordar las inequidades de género. En el ámbito de lo político, en salud y previsión social, los sucesivos planes nacionales de igualdad han articulado la labor del Estado para otorgar a las mujeres un lugar que supere su subordinación histórica (Valdés, 2009, 2010).

El gobierno de Bachelet cristalizó una historia de avances en la materia, con "un programa que, por primera vez, integra los objetivos de equidad de género transversalmente. A ello se agrega el rol de la Presidenta, quien incorporó la igualdad en su discurso" (Valdés, 2009, p. 279). No todos los temas han tenido la misma relevancia y prioridad y fueron surgiendo también nuevos desafíos. "Pero aún así (los avances) han logrado una gran transformación cultural que se palpa día a día en los discursos de los más diversos actores" (p. 280).

Por tales razones, cabe preguntarse por el correlato simbólico y por los significados que estas transformaciones han acarreado, específicamente en la prensa, así como sobre las construcciones de género en los diarios durante este periodo y qué significados se reproducen en los discursos de prensa.

\section{ESTADO DEL ARTE}

En el nivel nacional, la prensa ha tenido un rol preponderante, sobre todo cuando Chile recuperó la democracia en 1990, acompañando la transición desde el término de la dictadura hasta una paulatina consolidación de la institucionalidad. Sin embargo, a pesar del papel que el periodismo ha tenido en los cambios que el país ha experimentado en las últimas décadas en las áreas social, económica y política, el estudio empírico del periodista y del periodismo en Chile ha sido limitado (Mellado, 2010). Las investigaciones sobre los discursos periodísticos no han tenido el impacto suficiente para incorporar modificaciones en la formación de los profesionales.

Algunos estudios sobre periodismo en Chile han tenido como objetivo la promoción de espacios de encuentro para generar un debate 
público sobre el rol de los medios (Gibbs \& Parrini, 2009). Otro trabajo sobre la prensa nacional, evidencia una visión paradójica, ya que por una parte los lectores expresaron su reconocimiento al profesionalismo de los periodistas en Chile y, por otra, manifestaron su malestar por la falta de profundidad y de contextualización de las noticias en los diarios chilenos (FUCATEL, 2006). Las encuestas anuales del Consejo Nacional de Televisión (CNTV) arrojan resultados similares; la mayoría de la población declara informarse por la televisión abierta, especialmente por sus noticiarios centrales, pero en general, se manifiestan críticos hacia sus contenidos.

Estudios del Instituto de la Comunicación e Imagen de la Universidad de Chile (Cabalin \& Lagos, 2009), se centran en el análisis de la cobertura de los medios, en la diversidad de las pautas informativas, en la calidad de la información, en la relación de los periodistas con las fuentes, y la percepción de roles y actitudes de estos profesionales respecto de los medios. Esto permite conocer la autonomía de los periodistas y sus niveles de independencia, por medio de encuestas aplicadas a editores y reporteros (Gronemeyer, 2002).

En 2009, un estudio que aplicó focus group a lectores de la prensa nacional, permitió conocer la percepción de éstos sobre el tratamiento noticioso acerca del "desarrollo" en los diarios (Gibbs \& Parrini, 2009).

Respecto de los estudios que se han realizado sobre comunicación y género en particular, se destaca el trabajo desarrollado en la década de los ochenta por Pearson, Turner y Mancillas (1985), ya que a pesar de utilizar una perspectiva conductista, relacionan el género con el fenómeno de la comunicación, entregando una síntesis sobre los estudios anglosajones hasta esa fecha realizados y que aborda el procesamiento de la información, las diferencias en función del género, las autopercepciones de hombres y mujeres, la utilización masculina y femenina del lenguaje. Tipos de estudios que se han mantenido en la tradición anglosajona.

También en España existe un desarrollo del campo, desde 1997 cuando una mujer fue quemada por su expareja 5 luego de aparecer en televisión denunciando años de maltratos; a la fecha, la preocupación por los estudios en la materia han sido múltiples. Se encuentran los

5 Se trataba de Ana Orantes. 
trabajos de Vera y Ballesteros (2004), los que evidencian la asimetría de las mujeres en los medios de comunicación, los estereotipos de género, los imaginarios y los discursos. Alonso (2004), se centra en la presencia femenina en la televisión pública. Plaza (2005) y Sangro y Plaza (2010), aportan con el análisis de violencia de género en los medios, examinan el lenguaje periodístico, en las revistas y el cine, entre otros formatos. Chocarro (2007), Fernández y Pedreros (2007), abordan la temática de la mujer y las comunicaciones, contribuyendo con lineamientos para modificar el androcentrismo de la información. Fernández (2008), ha analizado el tipo e impacto de las campañas públicas contra la violencia machista en España en el público objetivo al cual van dirigidas. La preocupación por las representaciones de género en los medios de comunicación ha sido incorporado en la acción de algunos de ellos, en particular en la Radio y Televisión Española (RTVE, 2006), dando cuenta de la relevancia que ha adquirido el tema en ese país.

En América latina, también podemos encontrar trabajos sobre la representación de las mujeres y/o de las desigualdades de género en la publicidad, la prensa y en los medios de comunicación (Embade, 2006; Llanos, 2011; Santoro, 2009).

En Chile, se distinguen los trabajos realizados en cuatro grandes ámbitos, en el primero se cuentan aquellos que analizan proyectos de prensa feminista como alternativa a las voces hegemónicas, dentro de lo que se incluyen investigaciones de historia de la prensa de mujeres (Montero, 2008; Palomera \& Pinto, 2006). En el segundo, podemos encontrar estudios referidos a los discursos políticos, el género y la comunicación como eje (Hernández, 2008; López, 2009). En tercer lugar, hallamos publicaciones que acentúan las particularidades de la comunicación con perspectiva de género como una impronta que hay que incluir en el siglo XXI, tanto en el ejercicio del periodismo como en la formación de futuros comunicadores (DOMOS, 2011; Portugal \& Torres, 1996), y en cuarto lugar, los discursos sobre el género y la mujer en los medios de comunicación (Lagos, 2011), con especial énfasis en las cuestiones referidas a violencia física y simbólica (Berenguer, 2002; Errázuriz, 2002; Lagos, 2011; Naranjo, 2009). Precisamente, en este último ámbito, se enmarca el presente trabajo. 
FUNDAMENTO TEÓRICO: DISCURSO, GÉNERO Y PODER.

HILOS DE UN ENTRAMADO

La consolidación de la sociedad de la información y la complejidad e inmediatez de los procesos comunicacionales nos lleva a una preocupación especial por el uso del lenguaje. Este permite que se produzcan intercambios entre los sujetos, que se construyan identidades y que se produzcan por medio de la palabra los sentidos simbólicos (Charaudeau, 2003).

El discurso es un instrumento que permite entender las prácticas comunicacionales que se generan en la vida cotidiana. Su análisis se ha aplicado a la administración de la justicia, al contenido de los medios de comunicación, la educación, la medicina; desencadenando relaciones interpersonales en las que circula el poder (Foucault, 1992). El poder se encuentra entramado en los discursos como un elemento consustancial al mismo. Según Foucault y Deleuze, nos plantea Calveiro (2005), no se entiende como una posesión ni se encuentra en un lugar o centro determinado sino que circula de forma desigual. Así, en los discursos se pueden reconocer las identidades de género masculina y femenina como construcciones complementarias, excluyentes y desiguales. Son complementarias porque las funciones de cada una requieren imperiosamente de su otra "mitad": fuerte/débil, duro/blando, privado/público, etc. Excluyentes, porque los atributos asignados en cada caso no son deseables en el otro: femenino/masculino, suaves/duros, débiles/ agresivos, etc. Y desiguales, donde las características masculinas se construyen en una condición de superioridad; fuertes, decididos, arriesgados, impetuosos, resistentes, etc. En cambio ellas; débiles, inseguras, cautelosas, respetuosas, frágiles (Salinas, 2007; Vega-Centeno, 2006). La relación entre género y el lenguaje en los distintos aspectos de la vida social ha tenido como resultado un mayor grado de intervención consciente para controlar y moldear las prácticas lingüísticas acorde con los objetivos económicos, políticos e institucionales de la sociedad, estrategia que también está presente en los medios de comunicación, especialmente en la prensa.

Distintos autores coinciden en que cada situación de la interacción humana es específica y debe ser estudiada como un universo en sí mis- 
mo (Joas, 1998; Reynoso, 1998; Sandin, 2003). En esta dinámica los sujetos "crean" el significado y el orden social mediante una especie de negociación. Erving Goffman (citado en Joseph, 1999), destaca la práctica social en sus consecuencias y vocabulario, afirma que un motivo no es la fuente subjetiva de la acción, sino un acto de lenguaje que se inscribe en un discurso disponible, para los actores sociales y la interpretación de su conducta.

\section{DOMINACIÓN MASCULINA,}

VIOLENCIA SIMBÓLICA Y DISCURSO

La dominación masculina se ejerce transversalmente, ya que la preeminencia universalmente reconocida a los hombres se afirma en las estructuras sociales y en las actividades productivas y reproductivas, y se basa en una división sexual del trabajo que les confiere un lugar de privilegio. Estos esquemas funcionan como matrices en las percepciones, en los pensamientos y en las acciones de todos los miembros de la sociedad (Bourdieu, 2007).

De allí que la violencia simbólica se instaura como un mecanismo invisible, haciendo que en el colectivo se crea que no traerá consecuencias reales. Las estructuras de dominación masculina son producto del continuo trabajo de reproducción donde confluyen diversos agentes, ya sea hombres y/o mujeres como generadores de violencia, como también instituciones, entre las cuales sobresalen los medios de comunicación. Esta violencia tiene un "poder hipnótico", se expresa en sugerencias, seducciones, amenazas, reproches y órdenes; es una relación de dominación que circula a través de la complicidad (Bourdieu, 2007).

La supremacía masculina se impone como resultado de una sumisión paradójica, que es silenciada, amortiguada, insensible para sus propias víctimas y que se ejerce a través de las estrategias simbólicas de la comunicación y del conocimiento. La dominación se plasma en un sentimiento, en un estilo de vida, una manera de pensar, de hablar o comunicar (Bourdieu, 2007).

Entender los espacios de comunicación como espacios de poder es prioritario para el análisis de los valores que allí se intercambian. La mayoría de las investigaciones coinciden en reconocer el papel preponde- 
rante de los medios de comunicación de masas al momento de establecer y difundir la estructuras simbólicas, que atribuyen y fijan los roles de hombres y mujeres (Alonso, 2004); los medios son verdaderas máquinas simbólicas, como mecanismos de producción y reproducción ideológica.

\section{MetodologíA}

\section{Diseño de investigación}

Este estudio es descriptivo y tiene fines interpretativos. El carácter descriptivo permitió identificar los discursos y las construcciones de género en la prensa, durante el gobierno de la primera presidenta mujer en Chile, Michelle Bachelet Jeria (2006-2011). Así mismo, el carácter interpretativo posibilita explicar los sentidos del texto, develando los aspectos no observables en las ediciones especiales de la prensa.

\section{Recolección de la información}

Se revisaron exhaustivamente las "ediciones especiales" de los diarios La Cuarta, La Nación, La Tercera y Las Últimas Noticias. Ediciones que recopilan los acontecimientos periodísticos más significativos del año, de acuerdo con la línea editorial de cada medio, siendo esto último el primer criterio de selección que se consideró para definir el corpus de este estudio.

El segundo consideró la disponibilidad impresa del medio, para ello se revisó la única colección en existencia en los archivos de la Biblioteca Nacional de Chile (único del país) durante los meses de mayo y junio de 2011, logrando recopilar un total de 24 ediciones (véase Tabla 1), especiales en formato impreso. Se trata de cuatro de los cinco $^{6}$ diarios matutinos de circulación nacional pagados, de los cuales La Tercera y La Cuarta pertenecen al Consorcio Periodístico S. A. (COPESA); el primero, orientado a un público de clase media y alta, mientras que el segundo es el diario popular por excelencia, con un giro a la farándula en los últimos años. Mientras, Las Últimas Noticias es el matutino popular del holding de El Mercurio, con una pauta caracterizada por la especta-

6 El otro es El Mercurio, que no se consideró en este análisis debido a no contar con sus ediciones especiales anuales impresas. 
cularización de las noticias, y La Nación es propiedad del fisco, a través de una sociedad que está integrada también por miembros privados que tienen poder de veto. La Nación edita, además, el Diario Oficial.

Durante el segundo semestre de 2010, La Cuarta marcó casi 400000 lectores como promedio al día y es el segundo diario más leído detrás de El Mercurio; La Tercera registró cerca de 300000 lectores en promedio y Las Últimas Noticias, unos 309 000. La Nación, que a fines de 2010 dejó de circular en su versión impresa, en el primer semestre de ese año marcó alrededor de 22000 lectores en promedio al día.7 Obtuvimos un corpus que carece de homogeneidad y representatividad cuantitativa, las colecciones no se encuentran completas y tienen diferencias en sus ideologías, fines comerciales, porcentajes de lectoría, público, formatos, etcétera.

Sin embargo, las ediciones especiales representan la línea editorial de cada medio, y constituyen una síntesis anual y panorámica, donde cada medio revela los aspectos que considera relevantes del periodo, en diversos ámbitos del acontecer nacional o internacional. Condensa qué destacan y qué omiten. En este sentido, constituyen un corpus ejemplificador, no el único, que permitió reconocer las construcciones de género y la violencia simbólica presente en la prensa nacional.

\section{Análisis}

Para el análisis nos fijamos en las palabras como modo de conocer la estructura social y los procesos de significación y construcción de género presente en las ediciones especiales entre 2006-2011 (Murillo \& Mena, 2006). A través de una codificación del material recopilado con base en la Teoría Fundamentada (Strauss \& Corbin, 2002) y con la aplicación que de ella hacen Trinidad, Carrero y Soriano (2006). En la primera parte del análisis se identificaron los formatos periodísticos presentes en cada edición especial (corto/suelto/glosa de opinión, párrafo informativo, crónicas, entrevistas, reportajes, columnas y artículos de opinión), cualquiera que haya sido el ámbito de la información (deporte, política, espectáculo, nacional, internacional), alusiva a construcciones de género.

7 Según el Índice de Verificación de Circulación y Lectoría (IVCL) de la Asociación Nacional de la Prensa. 
TABLA 1

EDICIONES ESPECIALES POR DIARIO

\begin{tabular}{|c|c|c|}
\hline Diario & Fecha & Núm. de página \\
\hline \multirow[t]{6}{*}{ La Cuarta } & $29-12-2006$ & 3 \\
\hline & $28-12-2007$ & 3 \\
\hline & $26-12-2008$ & 3 \\
\hline & $29-12-2008$ & 3 \\
\hline & $10-12-2009$ & 9 \\
\hline & $31-12-2010$ & 2 \\
\hline \multirow[t]{4}{*}{ La Nación } & $31-12-2006$ & 12 \\
\hline & $30-12-2007$ & 3 \\
\hline & Diciembre 2008 & 48 \\
\hline & Diciembre 2009 & 8 \\
\hline \multirow[t]{5}{*}{ La Tercera } & $22-12-2006$ & 5 \\
\hline & $30-12-2007$ & 32 \\
\hline & $28-12-2008$ & 23 \\
\hline & $27-12-2009$ & Portada \\
\hline & $26-12-2010$ & 29 \\
\hline \multirow[t]{9}{*}{ Las Últimas Noticias } & $24-12-2006$ & 2 \\
\hline & $25-12-2006$ & 2 \\
\hline & $23-12-2007$ & 3 \\
\hline & $28-12-2007$ & Portada \\
\hline & $31-12-2007$ & 2 \\
\hline & $28-12-2008$ & 3 \\
\hline & $27-12-2009$ & Portada \\
\hline & $31-12-2009$ & 3 \\
\hline & $31-12-2010$ & 2 \\
\hline
\end{tabular}

Segundo, de ellos se analizaron los epígrafes, titulares, bajadas y lead de cada formato periodístico identificado y tercero, en los discursos seleccionados distinguimos luego, las categorías abiertas y figuras discursivas como metáforas, ironías y metonimias, que se utilizan para la formulación del discurso indirecto (véase Tabla 4). Las metáforas son una de las más importantes figuras literarias presentes en el discurso, su proceso de desviación (trópico) consiste en establecer una intersección 
analógica entre dominios diferentes. Las ironías se definen como una expresión contraria a lo que se piensa, de tal forma que por el contexto, el receptor puede reconocer la verdadera intención del emisor. Por último, las metonimias constituyen un tropo, ya que consiste en la designación de un objeto por el nombre de otro, fundándose en relaciones de causalidad, procedencia o sucesión existentes entre los significados de ambos términos, según los diferentes modos de contigüidad, se producen diversos tipos de metonimia (Charaudeau \& Maingueneau, 2005; Santillana, 1996). Finalmente, se ordena el análisis en matrices, para lo cual se transcribió el discurso de prensa en forma textual, se mantuvieron las mayúsculas y minúsculas. Se usa letra cursiva para las notas de las investigadoras.

\section{Resultados}

En las construcciones de género relacionadas a lo femenino identificamos en el discurso de la prensa el uso de metáforas, como un vehículo comunicacional que direcciona el significado del texto, polarizando en dos sentidos el imaginario colectivo sobre el género femenino, es decir, el conjunto de imágenes, símbolos y representaciones de la mujer (Vega-Centeno, 2006), ya sea con una clara connotación sexual o como medio de control social. En la sexualización del texto, el cuerpo femenino es representado con diferentes matices dentro de un mismo constructo cultural.

Estas construcciones de género develan que en el subtexto, lo implícito tiene una carga valorativa que prejuzga la identidad femenina (a la vez que la sojuzga). El cuerpo es la base de la percepción y de la organización de la vida humana, tanto en lo biológico como en lo social; cada sociedad -afirma Levi Strauss (1974)- produce cuerpos útiles para las relaciones sociales que las sustentan, cuerpos para la dominación o la sumisión, surgiendo formas clasificatorias, como dominios culturales de conocimiento y de valoración.

Las construcciones culturales sobre el género implican expresar formas de representación del propio cuerpo dentro de un medio dado, de tal modo que, "el género es la representación mental de lo sexual" (Lemlij, citado en Vega-Centeno, 2006, p. 18). En este constructo, la desvaloración se naturaliza y se expresa en un reduccionismo identitario. 


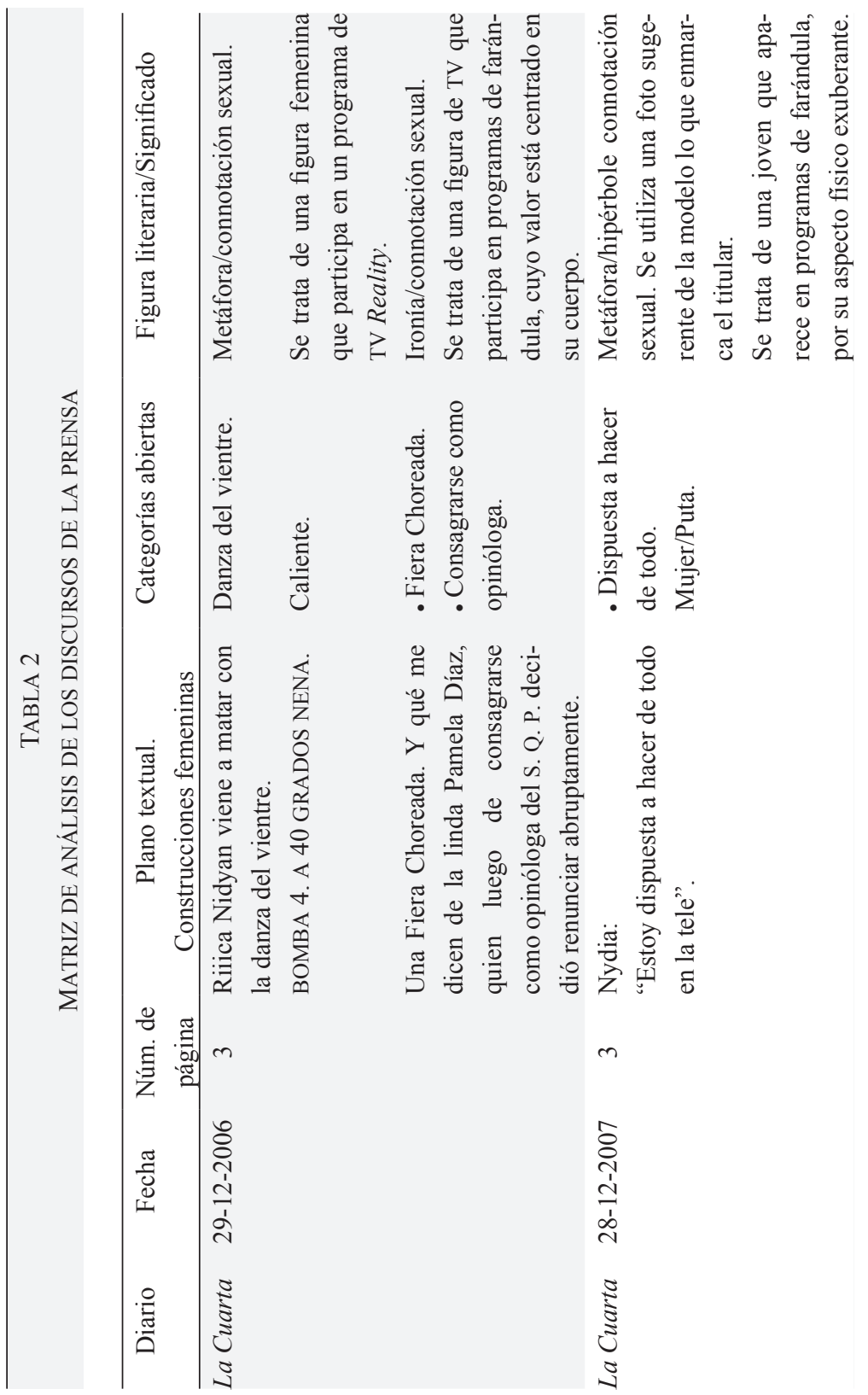




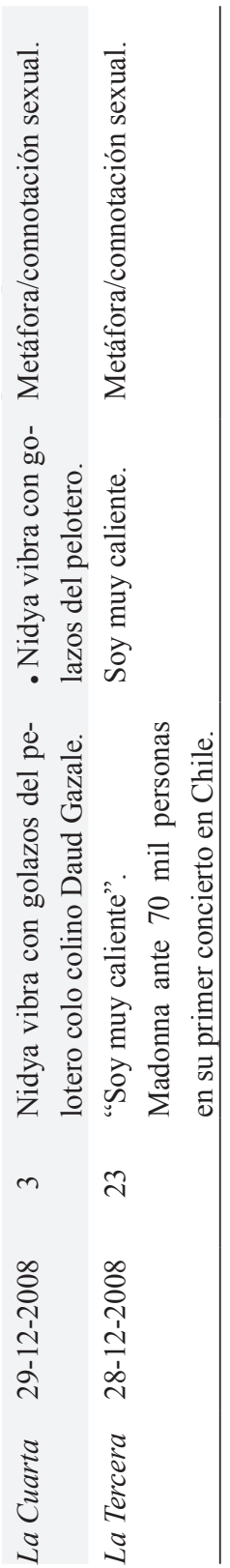


El cuerpo de las mujeres es un territorio en el que se imprime un símbolo, donde la sexualidad es un objeto más de consumo, es el eje articulador de las interacciones y la base del imaginario colectivo (Salinas \& Barrientos, 2011).

Una segunda construcción identificada preferentemente en los discursos de las ediciones especiales de la prensa son metáforas que expresan el control social, que se ejerce cuando las mujeres se contraponen al imaginario colectivo sobre el género femenino en la sociedad patriarcal. Así mismo, los mecanismos de control social se encuentran vinculados al poder, siendo éste una forma de control que un grupo ejerce sobre otro y puede extenderse hasta las acciones y pensamientos del grupo dominado. Estos mecanismos de control social también se despliegan sobre el texto y el habla. La dominación que se implementa de forma discursiva implica un acceso preferente al texto, que se toma como base o recurso de poder (Van Dijk, 1997). Precisamente la diferencia masculina/femenina es una distinción privilegiada para establecer relaciones de poder. Scott en 1990 afirmaba que: "el género es el primer campo por medio del cual el poder es articulado" (citada en Vega-Centeno, 2006, p.19).

En las construcciones de género masculina el uso de metáforas es menor y solo se registra en el diario La Cuarta. En ellas se hace alusión principalmente a las características asociadas al imaginario colectivo que caracteriza ser hombre: fuerza, autoridad, liderazgo y potencia sexual.

En general, en lo que se refiere a lo masculino, el uso de metáforas se destaca especialmente en las ediciones especiales de La Cuarta, un diario popular, así como también es el recurso preferente para referirse al imaginario colectivo sobre lo femenino. Gracias al uso de la ironía, se expresa lo contrario de lo que se piensa. En las ediciones especiales de la prensa para el periodo analizado, esta figura literaria la hallamos solo en aquellos casos que se refieren a construcciones de género femeninas.

Las ironías tienen un marcado sentido sexista, coincidente con las metáforas descritas anteriormente. En las formulaciones irónicas se cuestiona el comportamiento de las mujeres y se les connota como fáciles; a través de la ironía, en los ejemplos consignados, se le otorga al discurso una carga valórica-sexista que cuestiona el imaginario femenino, donde el subtexto tiene un sentido binario: las "mujeres" son desin- 


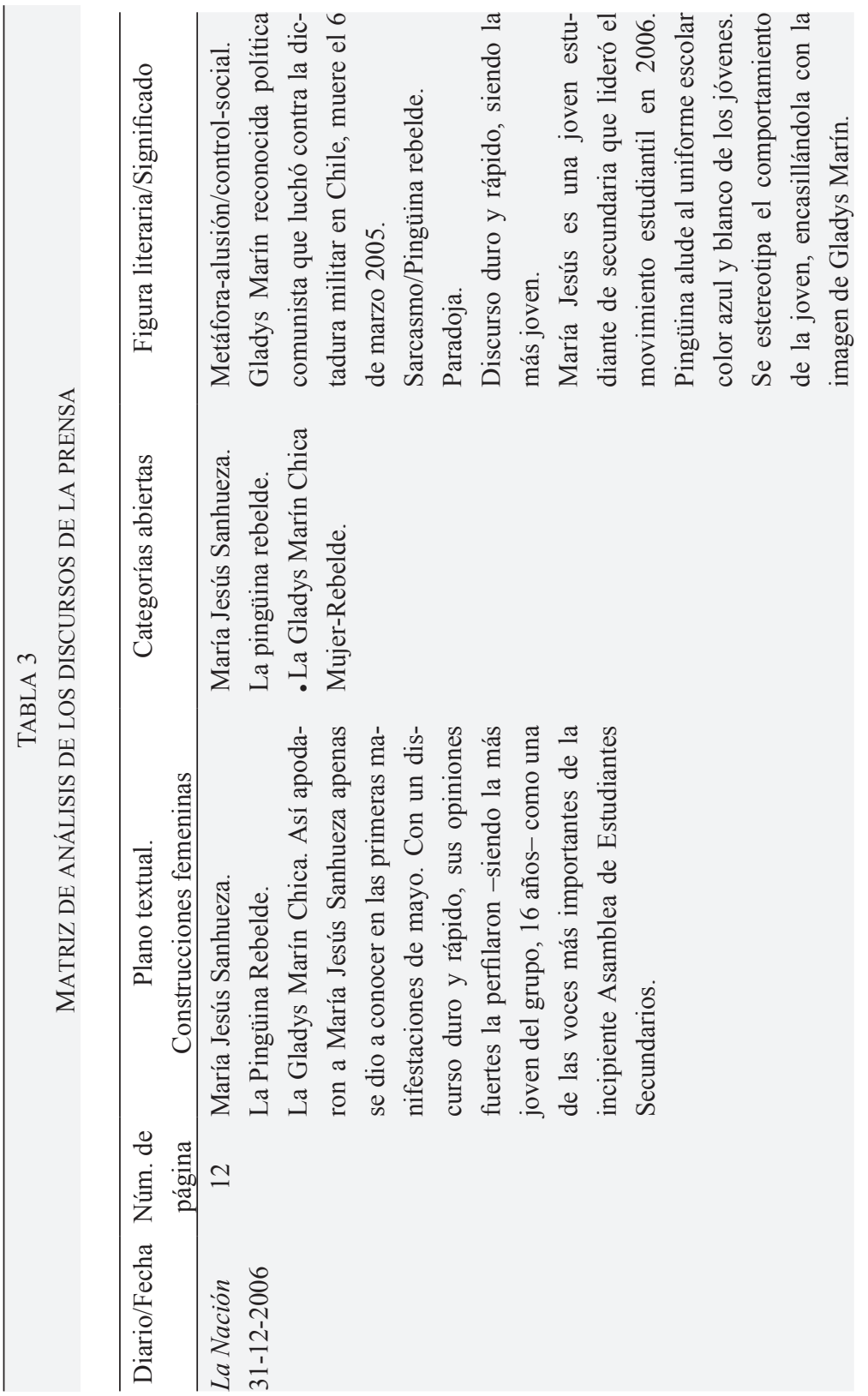




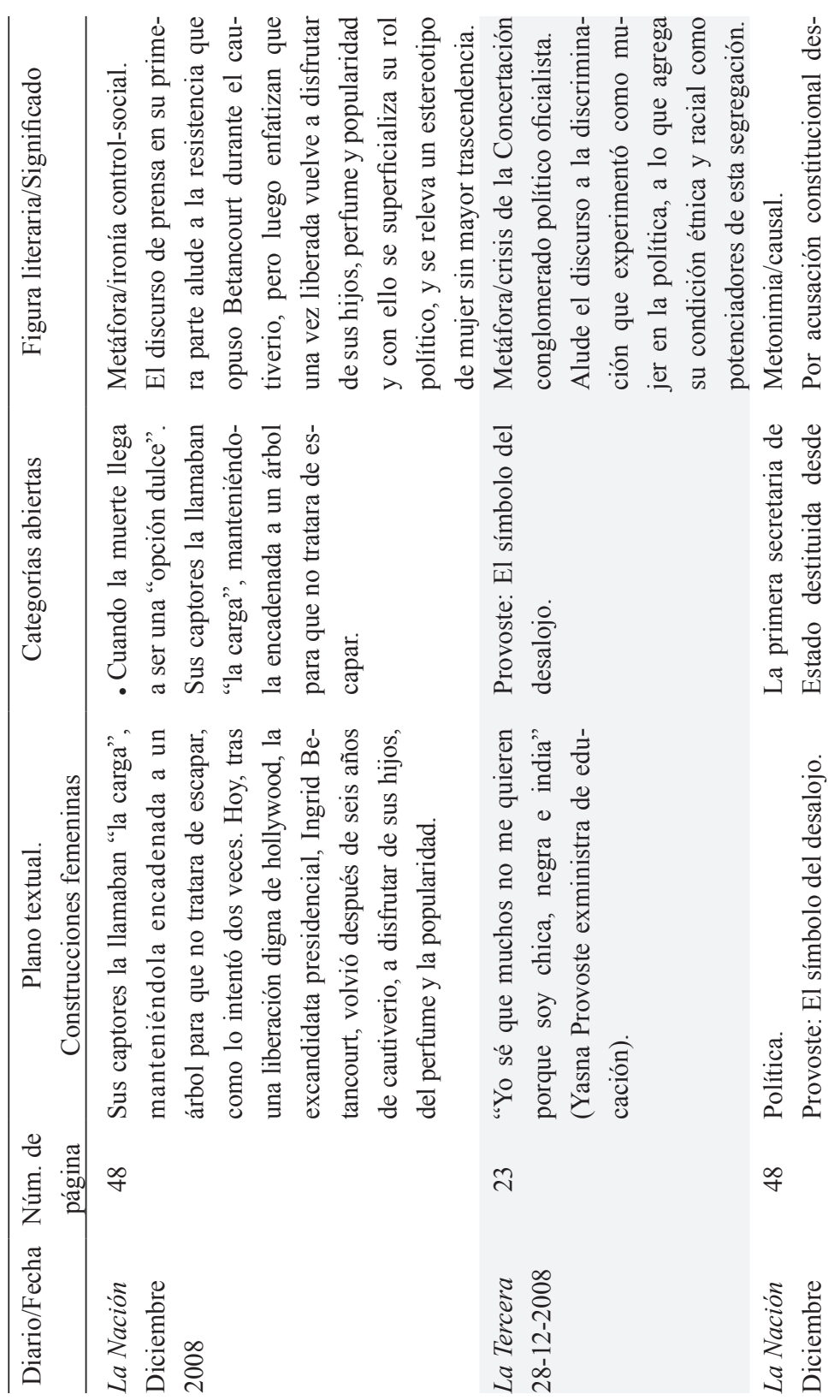




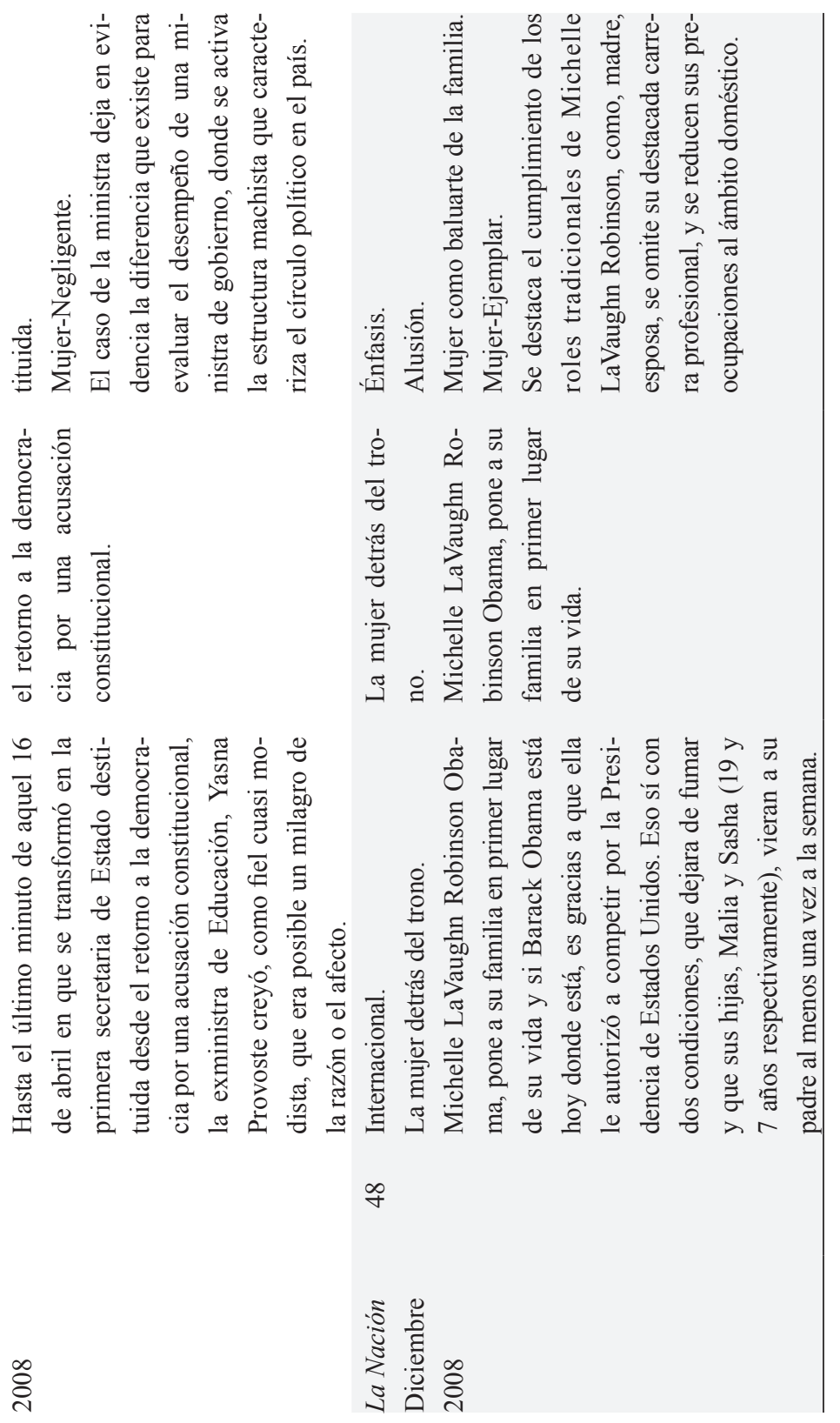




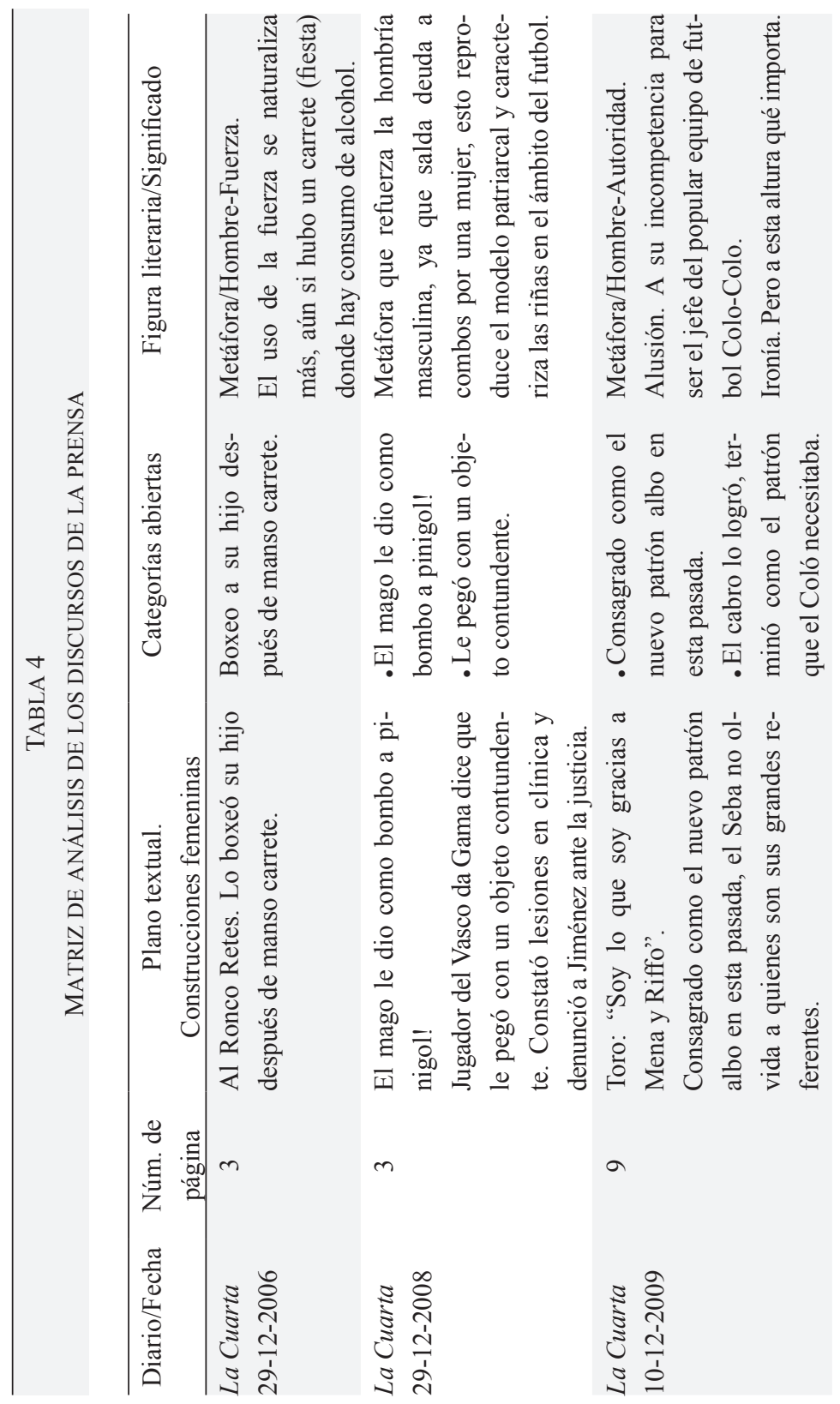



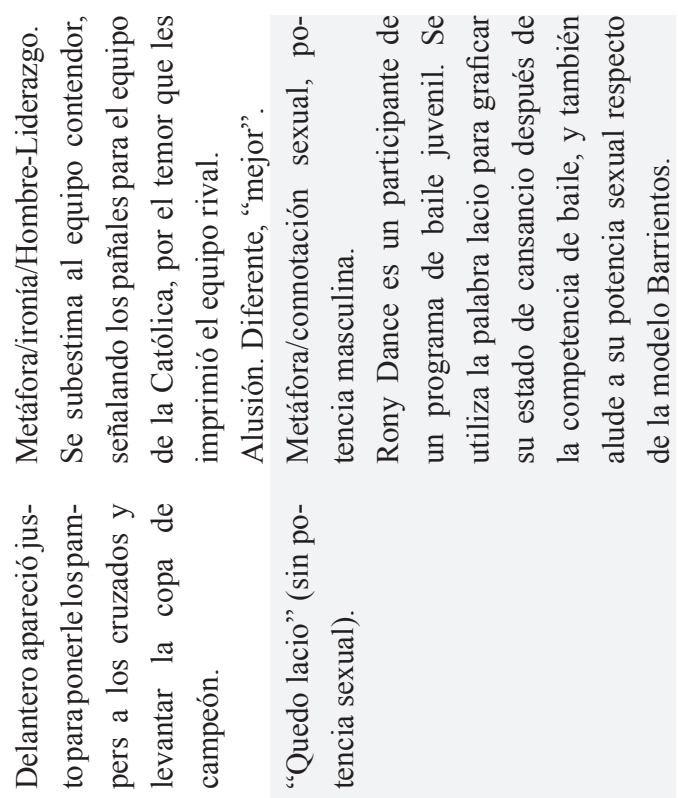

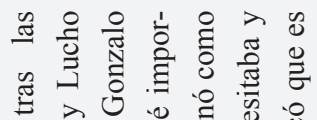

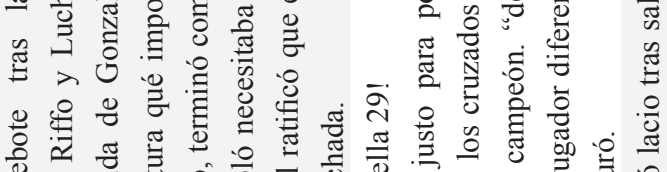

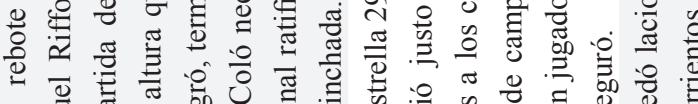

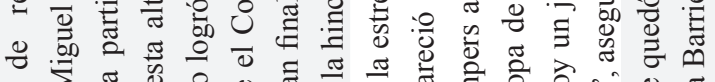

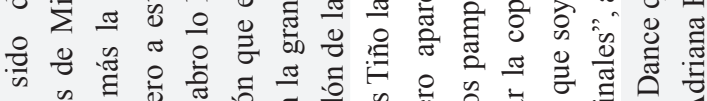

\%

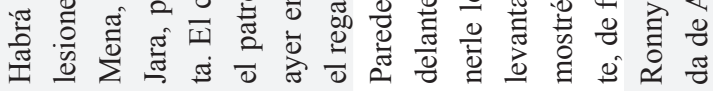

a

$m$

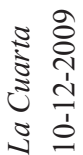

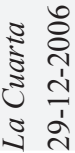


hibidas/recatadas, muestran/ocultan, son sexuales/asexuadas, amantes/ esposas, viejas/jóvenes; en definitiva, contravienen el constructo asociado al género en la cultura patriarcal (sumisas, femeninas, maternales, cuidadoras, nutricias, entre otras).

Al mismo tiempo, identificamos en los discursos de la prensa analizados el uso de ironías, especialmente en referencia a la figura presidencial de Michelle Bachelet. Reconocemos tres aspectos centrales: a) el escaso apoyo que tendría de la ciudadanía, b) el error de haber establecido un gabinete paritario en su gobierno y c) la falta de competencia para ejercer el cargo de presidenta de la República.

Lo anterior ejemplifica el uso de un lenguaje indirecto que facilita expresiones de discriminación y violencia simbólica en el texto. En los ejemplos, la figura femenina es central como eje articulador de los discursos sexistas.

Finalmente, la tercera figura literaria identificada en las ediciones especiales de prensa examinadas durante el periodo son las metonimias. Los constructos de género analizados en forma de metonimia, al igual que la ironía, aluden preferentemente a la figura femenina. En cambio, hay escasos ejemplos de constructos masculinos. Así mismo, las metonimias se diferencian en expresar un campo mayor de sentido en el discurso, se alude a negligencia, incompetencia, xenofobia y sexismo. También, el elemento común de todas ellas es el uso reiterado de un lenguaje indirecto para sostener la desvaloración de la identidad de género femenina y sus constructos culturales, como relaciones causales que reproducen discursos como los que se observan en la Tabla 7.

Respecto de las construcciones del género masculino identificamos solo en un segmento del texto una formulación que utiliza la metonimia, para establecer una relación causal, en la que el hombre ejerce fuerza física para resolver un conflicto interpersonal, cumpliendo de esta manera con el imaginario colectivo de lo masculino, donde la violencia es un mecanismo válido y esperado en la relaciones que establecen los hombres. 


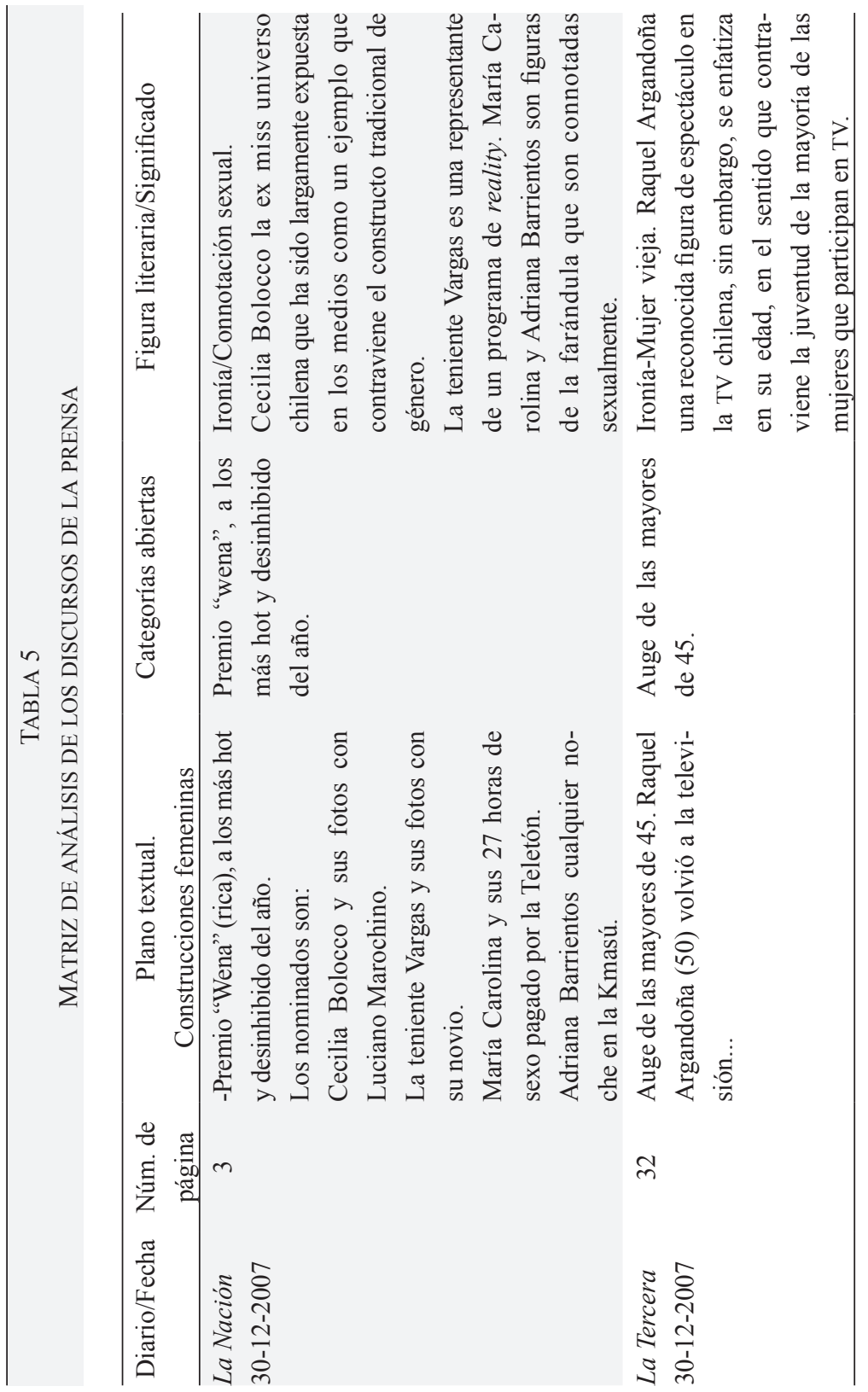




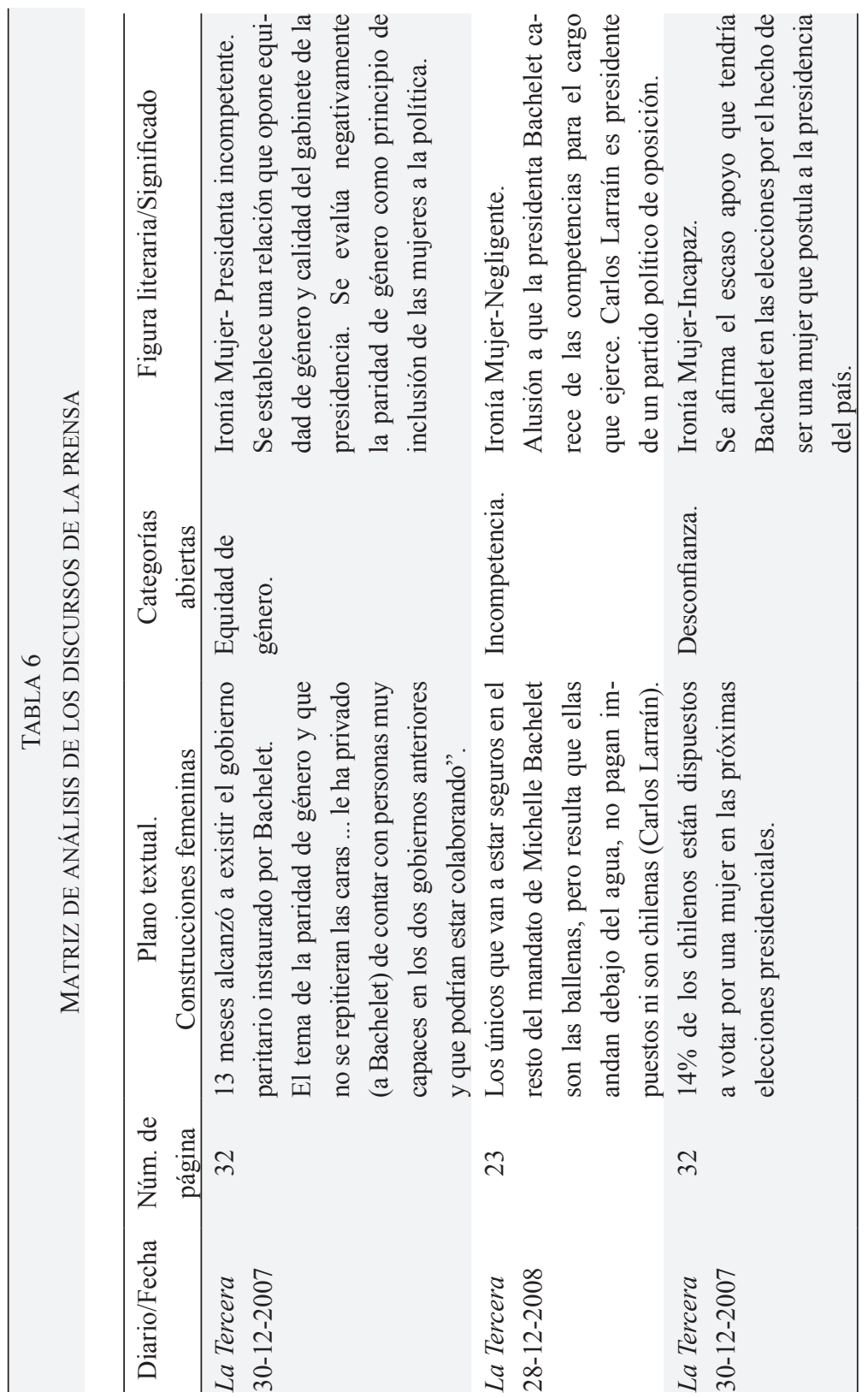




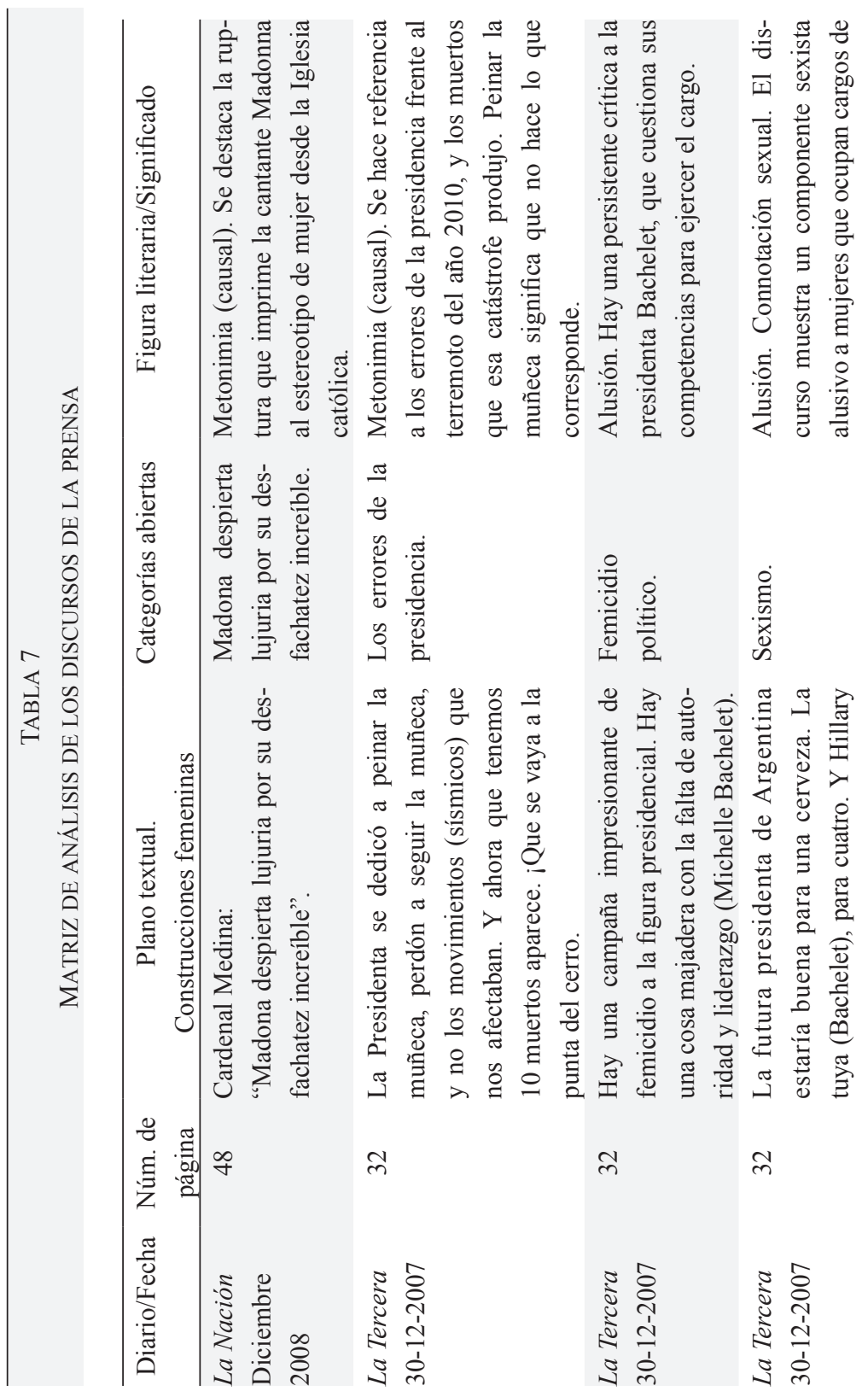




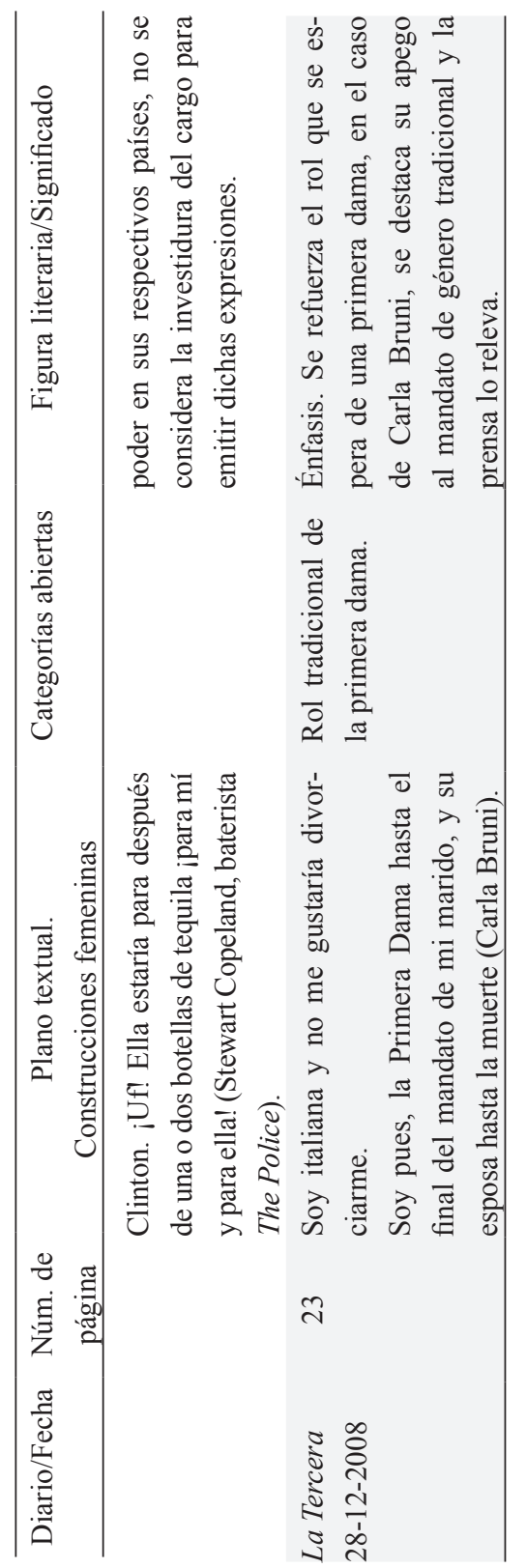




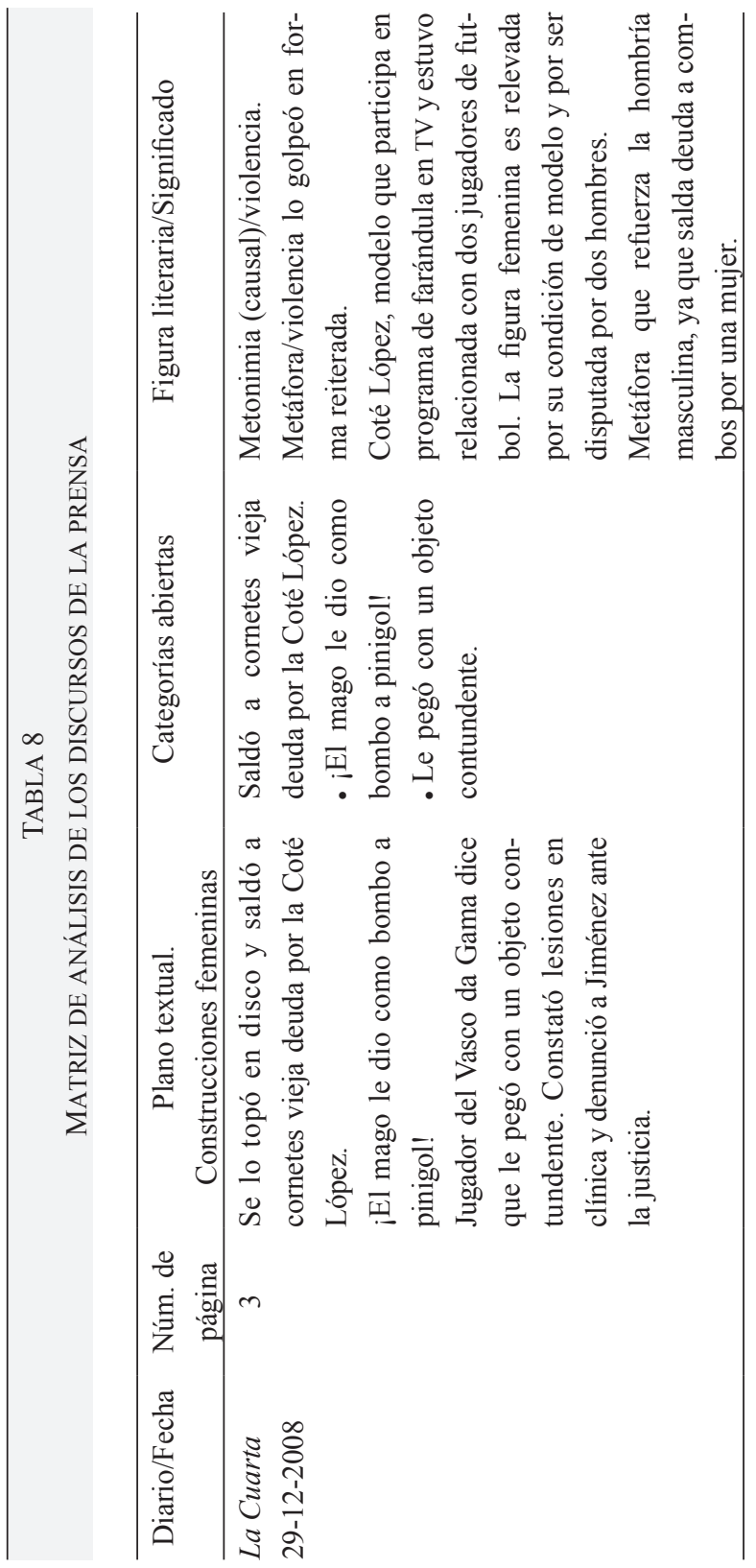




\section{CONCLUSIONES}

Este trabajo hace un análisis descriptivo e interpretativo de los discursos sobre el género contenidas en las ediciones especiales de la prensa en Chile, durante el gobierno de Michelle Bachelet (2006-2011), la primera presidenta mujer chilena.

Identificamos figuras literarias que se caracterizan por utilizar un lenguaje indirecto, a través de ellas reconocimos construcciones de género en que subyacen la discriminación y la violencia simbólica. En la revisión teórica destacamos la relevancia creciente que han tenido los estudios del discurso y el género en el ámbito de las comunicaciones; así mismo confirmamos los escasos avances que se han alcanzado a favor de disminuir el sexismo en el lenguaje y la discriminación en una muestra concreta de prensa.

A partir de los resultados, una conclusión importante se relaciona con el lenguaje indirecto que actúa como vehículo comunicacional y que es utilizado para referirse al género femenino. Con ello, el sentido del discurso ampara la naturalización del sexismo, el control social y la xenofobia.

Las conclusiones coinciden con los resultados de estudios anteriores, en el sentido de que las identidades de género recreadas en la prensa reproducen constructos binarios, preferentemente excluyentes y desiguales, en los cuales las mujeres son exponentes principales.

Las construcciones esencialistas de género las posicionan a ellas en torno a dos ejes centrales; uno, exacerba la sexualización de su identidad y, en otro, los discursos se utilizan como dispositivos de control social. Esto último activa los estereotipos femeninos que contravienen la representación social que existe sobre las mujeres, siguiendo el modelo de la sociedad patriarcal; de acuerdo a los ejemplos descritos, ellas son enunciadas como "agresivas, desfachatadas, incapaces, calientes". Se trata, evidentemente, de expresiones del poder vehiculizadas en el discurso, en forma negativa.

Por lo tanto, los hallazgos nos permiten defender empíricamente los sustentos teóricos que señalan que los espacios de comunicación, ya sea prensa $u$ otros, son de poder donde se intercambian valores y difunden estructuras simbólicas, fijándose roles de género, como me- 
canismos de producción y reproducción ideológica y epistemológica. Otro hallazgo común con otras investigaciones se relaciona con la violencia simbólica, la que es transversal en los discursos de la prensa analizada. La violencia simbólica, como mecanismo de discriminación, se advierte en cualquier ámbito: la política, la cultura, el deporte $\mathrm{y}$, cómo no, el periodismo, entre tantos otros.

Sin embargo, constatamos, especialmente en el periodo examinado, la fuerza del discurso político asociado a la primera mujer presidenta en el país y a algunas de las ministras que componen su gabinete y que hay estereotipos sobre la figura presidencial que tienen claramente una connotación negativa: “es incapaz, no tiene liderazgo, se equivoca, no tiene autoridad", entre otros.

Por lo tanto, respecto de las interrogantes que orientaron este estudio afirmamos que los discursos sobre las identidades de género en la prensa bajo la primera administración de una mujer en el país no han producido una transformación efectiva en la manera de significar lo femenino; más bien existe continuidad y escasos cambios en este sentido. Confirmándose la hipótesis inicial de este trabajo, en orden a que existe una estrecha relación entre el discurso como práctica social, el género como constructo sociocultural y la violencia simbólica. Por lo mismo, es necesario profundizar en este tipo de investigaciones, de tal manera de deconstruir los esencialismos que sustentan las identidades de mujeres y hombres y que se reproducen en el discurso, en general, y en los discursos de los medios de comunicación, en particular.

Las relaciones de poder son elementos discursivos, denotan, marcan el lugar que ocupan los sujetos en las relaciones y en los contextos dados. Así mismo, el discurso modela a la sociedad y a la cultura, es decir, el lenguaje contribuye a la reproducción y/o transformación de la sociedad, y de ahí la importancia de su estudio.

Por último, las figuras literarias identificadas son una expresión del lenguaje que encuadra y legitima la discriminación de género y, específicamente, la dominación masculina. Más aún, ésta se refiere a un fenómeno que subyace en el lenguaje y en la construcción social de los sujetos. El mayor uso de este tipo de recursos lingüísticos en el diario La Cuarta, aunque no es el único, establece una relación estrecha entre el factor cultural y económico que encierra este tipo de prensa popular, 
orientada a segmentos socioeconómicos medios y bajos y que es una estrategia ampliamente utilizada en este tipo de periodismo en el nivel internacional. Estamos frente a dispositivos de control que son retroalimentados en un sistema comunicacional globalizado.

\section{Bibliografía}

Alonso, A. (2004). Mujeres en los medios, mujeres de los medios. Imagen y presencia femenina en las televisiones públicas, Canal Sur TV. Barcelona, España: Editorial Icaria.

Berenguer, C. (2002, junio). La tragedia del norte de Chile en Alto Hospicio. Nomadías, 4 (6), 132-134.

Bourdieu, P. (2007). La dominación masculina. Barcelona, España: Editorial Anagrama.

Cabalin, C. \& Lagos, C. (2009). Libertad de expresión y periodismo en Chile: presiones y mordazas. Palabra Clave, 12, (1), 37-59.

Calveiro, P. (2005). Familia y poder. Argentina: Libros de la Araucaria. Charaudeau, P. (2003). El discurso de la Información. La construcción del espejo social. España: Gedisa editorial.

Charaudeau, P. \& Maingueneau, D. (2005). Diccionario de análisis del discurso. Madrid, España: Editores Amorrortu.

Chocarro, S. (2007). Nosotras en el país de las comunicaciones. Barcelona, España: Editorial Icaria.

DOMOS. (2011). La violencia tiene mil caras. Guía para profesionales y comunicadores/as de medios de comunicación en violencia contra las mujeres. Santiago de Chile, Chile: UNICEF/UNFPA/SERNAM/DOMOS.

Embade, H. (2006). O tratamento da mulher na publicidade e nos meios de comunicaçao. Comunicación e Cidadanía, 1, 479-482.

Errázuriz, P. (2002, junio). Violencia real, violencia simbólica: los crímenes de Alto Hospicio. Nomadías, 6 (4), 142-146.

Fernández, D. (2008). De parricidio a violencia machista: apuntes para una reflexión sobre la representación de los malos tratos en once años de información periodística. En A. I. Blanco (Coord.), Cuestiones de género: de la igualdad y la diferencia (pp. 291-316). España: Universidad de León.

Fernández, P. \& Pedreros, A. (2007). La mujer y la sociedad de la información. ¿Existe un lenguaje sexista?. Madrid, España: Editorial Fragua. 
Foucault, M. (1992). Microfisica del poder. Madrid, España: La Piqueta. Fries, L. (2010). Avances y desafíos en torno a la autonomía política de las mujeres. En T. Valdés (Ed.), ¿Género en el poder? El Chile de Michelle Bachelet (pp. 113-136). Santiago de Chile, Chile: Corporación de Estudios para el Desarrollo de la Mujer, CEDEM.

FUCATEL. (2006). Imágenes y percepciones de la prensa chilena. Los diarios según sus lectores. Recuperado el 16 de agosto de 2011 de http://www.observatoriofucatel.cl/imagenes-y-percepciones-de-laprensa-chilena-los-diarios-segun-sus-lectores/

Gibbs, C. \& Parrini, V. (2009). Noticias sobre desarrollo de la prensa chilena. Santiago de Chile, Chile: Observatorio de medios de FUCATEL.

Gronemeyer, M. (2002). Periodistas chilenos: el reto de formar profesionales autónomos e independientes. Cuadernos de Información, 15 , pp. 52-70.

Hernández, M. (2008, septiembre). Michelle Bachelet: l'incarnation de la société chilienne des années 2000 à travers son discours de campagne. París, Francia: IHEAL UFR Sciences Politiques/Université de París 3 Sorbonne Nouvelle.

Joas, H. (1998). Interaccionismo simbólico. En A. Giddens, J. Turner et al. La teoría social hoy (pp. 112-154). Madrid, España: Editorial Alianza Universidad.

Joseph, I. (1999). Erving Goffman y la microsociología. Madrid, España: Editorial Gedisa.

Lagos, C. (2011). El aborto en la televisión: apuntes sobre cuerpos pedagogizados, medios de comunicación y discursos inmunitarios. En J. Pavez, \& L. Kraushaar (Eds.), Capitalismo y pornología. La producción de los cuerpos sexuados (pp. 462-486). Santiago de Chile: Chile; Qillqa/Universidad Católica del Norte/Ocho Libros Editores.

Levi-Strauss, C. (1974). Antropología estructural. España: Ediciones Paidós. Recuperado el 16 de agosto de 2011 de http://es.scribd.com/ doc/11301370/LeviStrauss-Antropologia-Estructural

Llanos, B. (2011). Ojos que no ven: cobertura mediática y género en las elecciones latinoamericanas. Perú: ONU Mujeres/IDEA Internacional. 
López, H. (2009). La imagen de la mujer en política. La campaña electoral televisiva de Michelle Bachelet. Cuadernos de Información, 24 (1), 7-18.

Mellado, C. (2010). Análisis estructural de la investigación empírica sobre el periodista latinoamericano. Comunicación y Sociedad, 13, 125-147.

Montero, C. (2008). Camino a la sala de redacción: los orígenes de la prensa de mujeres en Chile. Cien años de prensa en Chile (pp. 12-35). Santiago de Chile, Chile: Círculo de Periodistas de Chile.

Murillo, S. \& Mena, L. (2006). Detectives y camaleones: el grupo de discusión. Una propuesta para la investigación cualitativa. Madrid, España: Talasa Ediciones.

Naranjo, V. (2009). Los asesinatos contra mujeres según TVN: relatos televisivos que normalizan, invisibilizan y reproducen la violencia contra las mujeres. Nación golpeadora manifestaciones y latencias de la violencia machista (pp. 106-114). Santiago de Chile, Chile: Red Chilena contra la Violencia Doméstica.

Palomera, A. \& Pinto, A. (Comps.). (2006). Mujeres y prensa anarquista en Chile (1897-1931). Santiago de Chile, Chile: Ediciones Espíritu Libertario.

Pearson, J., Turner, L. \& Mancillas, T. (1993). Comunicación y género. Barcelona, España: Paidós Comunicación.

Plaza, J. (2005). Modelos de varón y mujer en las revistas femeninas para adolescentes. La representación de los famosos. España: Editorial Fundamentos.

Portugal, A. \& Torres, C. (Eds.). (1996). Por todos los medios. Comunicación y género. Ediciones de las Mujeres, 23. Santiago de Chile, Chile: Isis Internacional.

Radio y Televisión Española-RTVE. (2006). Representación de la violencia de género en los informativos de TVE. Madrid, España: Instituto Oficial de Radio y Televisión.

Reynoso, C. (1998). Corrientes en antropología contemporánea. Buenos Aires, Argentina: Editorial Biblos.

Salinas, P. (2007). Los discursos masculinos como dispositivos de control y tensión en la configuración del liderazgo y empoderamiento femenino. Revista de Estudios Feministas, 15 (3), 541-562. 
Salinas, P. \& Barrientos, J. (2011). Los discursos de las garzonas en las salas de cerveza del norte de Chile. Género y discriminación. Polis Revista Académica de la Universidad Bolivariana, 29, 433-461.

Sandin, M. P. (2003). Investigación cualitativa en educación. Fundamentos y tradiciones. Madrid, España: Mc Graw Hill.

Sangro, P. \& Plaza, J. (2010). La representación de las mujeres en el cine y la televisión contemporánea. España: Laertes Ediciones.

Santillana. (1996). Diccionario Salamanca de la lengua española. Barcelona, España: Santillana.

Santoro, S. (Ed.). (2009). Sin nosotras, se les acaba la fiesta. América latina en perspectiva de género. Bogotá, Colombia: Centro de Competencia en Comunicación para América Latina/Friedrich Ebert Siftung/Artemisa Comunicación.

Strauss, A. \& Corbin, J. (2002). Bases de la investigación cualitativa. Técnicas y procedimientos para desarrollar la teoría fundamentada. Medellín, Colombia: Editorial Universidad de Antioquia.

Trinidad, A., Carrero, V. \& Soriano, R. (2006). Teoría fundamentada "Grounded Theory". La construcción de la teoría a través del análisis interpretacional. Madrid, España: Centro de Investigaciones Sociológicas.

Valdés, T. (2009). La equidad de género: democracia en lo público y en lo privado. En Y. Quiroga \& J. Ensignia (Eds.), Chile en la Concertación, 1990-2010: una mirada crítica, balance y perspectivas (pp. 271-299). Santiago de Chile, Chile: Friederich Ebert Stiftung.

Valdés, T. (Ed.). (2010). ¿Género en el poder? El Chile de Michelle Bachelet. Santiago de Chile, Chile: Observatorio de Género y Equidad/UNDEF/UNIFEM/ Corporación de Estudios para el Desarrollo de la Mujer, CEDEM.

Van Dijk, T. (1997). Racismo y análisis crítico de los medios. Barcelona, España: Editorial Paidós.

Vega-Centeno, I. (2006). La tradición oral como fuente para el estudio del imaginario de género. En L. Rebolledo \& P. Tomic (Coords.), Espacios de género, imaginarios, identidades e historia (pp.17-38). México: Cuadernos del CIC/Museo UABC. 
Vera, M. \& Ballesteros, R. (2004). Mujeres y medios de comunicación. Imágenes, mensajes y discursos. Málaga, España: Universidad de Málaga.

Fecha de recepción: 24/10/11. Aceptación: 26/05/12. 